\title{
"No Silver Bullet Solution" Cruel Optimism and Canada's COVID-19 Public Health Messages
}

\author{
Christina Holmes \\ St. Francis Xavier University \\ Udo Krautwurst \\ University of Prince Edward Island
}

\author{
Kate Graham \\ St. Francis Xavier University \\ Victoria Fernandez \\ St. Francis Xavier University
}

\begin{abstract}
Science twines through many of the discussions related to hope for a return to normalcy within public discussions of COVID-I9. The framings of techno-scientific solutions for COVID-I9 are similar to those that are presented to address many societal problems. The messy scientific and regulatory underpinnings of this desired silver bullet rarely make it fully into view. Technoscientific-related hope and its associated affects can operate as a kind of "cruel optimism" (Berlant 20IO, 20II). It can be an affective response to return to life as "normal" that is psychologically soothing, even as its enactment may replicate destructive social, political, and economic structures. Hope and technoscience thread throughout the interactions between journalists and health officials in the health press briefings in the first wave of the COVID-I9 pandemic. Technoscientific complexity that challenges the desire to return to normal is rarely brought up in Ontario and Nova Scotia public health briefings. But when it is, health officials in this zone of interaction balance explanations of scientific reality and caution, while attempting to not crush hope for a techno-scientifically mediated return to normal. As such, public health discourse obscures or tempers cruel optimism rather than directly confronting it.
\end{abstract} Keywords: anthropology of science; public health; Canada; cruel optimism; hope; COVID-I9; vaccines; diagnostic tests; proteomics; neuroscience 
Résumé: La science est au cœur de nombreux débats publics en lien avec l'espoir d'un retour à la normale dans le cadre de la COVID-I9. Les solutions technoscientifiques pour la COVID-I9 sont présentées de manière similaire à celles mises en avant pour traiter de nombreux problèmes de société. Les fondements scientifiques et réglementaires incertains de la solution miracle souhaitée sont rarement pleinement visibles. Les espoirs suscités par les technosciences et les affects qui leur sont associés peuvent fonctionner comme une sorte «d'optimisme cruel» (Berlant 20IO; 20II). Il peut s'agir d'une réponse affective à l'idée d'un retour à la vie «normale» qui serait psychologiquement apaisante, même si ce retour peut reproduire des structures sociales, politiques et économiques destructrices. Pendant la première vague de la pandémie de COVID-I9, l'espoir et la technoscience ont imprégné les interactions entre journalistes et responsables de la santé lors des points de presse sur la santé. La complexité technoscientifique qui remet en cause les espoirs d'un retour à la normale est rarement évoquée dans les points de presse sur la santé publique en Ontario et en Nouvelle-Écosse. Mais lorsqu'elle l'est, les responsables de la santé dans cette zone d'interaction mettent en balance prudence et explications de la réalité scientifique, tout en évitant d'étouffer l'espoir d'un retour à la normale par l'intermédiaire des technosciences. Ainsi, le discours de la santé publique occulte ou tempère l'optimisme cruel plutôt que de l'affronter directement.

Mots-clés: anthropologie de la science; santé publique; Canada; optimisme cruel; espoir; COVID-I9; vaccins; tests de diagnostic; protéomique; neuroscience

But we can't, at this stage, just put all of our focus in the hopes that [a vaccine] is the Silver Bullet solution. - Dr. Theresa Tam, Canada's Chief Public Health Officer

All of the affective paradoxes of the political in relation to mass demands for social change uttered from the impasse of the present extend from this, cruel optimism's double bind: even with an image of a better good life available to sustain your optimism, it is awkward, and it is threatening to detach from what is already not working. - Lauren Berlant, Cruel Optimism (20II, 263) 


\section{Technosalvation and/as Cruel Optimism?}

COVID-I9 has put biomedical science and technology in the forefront of public discussions in Canada in a number of ways. Scientific evidence about the efficacy of face masks is debated on Facebook, questions are raised about virus testing, and things will not get back to normal, we are told, "until there is a vaccine." But as anthropologists who have spent time within the scientific "black box" of the laboratory, who have seen the myriad complications of "science in action" (Latour I987), we question the extent to which the hope that is pinned on technoscience is a type of "cruel optimism" (Berlant 20IO; 20II).

Technological solutions have long been a North American cultural favourite for solving social problems (Davis-Floyd 1994; Reynolds 199I). From promises of the human genome to solve myriad problems (Fortun 2008), to the use of ideal seed varieties to meet development goals (Montenegro de Wit 20I6; Stone and Glover 2017), to more recent investment by the Gates Foundation in genetically modified mosquitos as a "flying public health tool" (Beisel and Boëte 20I3); the technological silver bullet has had a profound cultural pull to provide hope for the future. Indeed, there is a longstanding anthropological and ethnographically informed literature on the work of hope in biomedical settings (DelVecchio Good 200I; DelVecchio Good et al. I990; Franklin and Roberts 2006; Novas 2006). In this way, technoscience has the potential and ability to play a key role in what Berlant (2010) discusses as cruel optimism (94-95): "'Cruel optimism' names a relation of attachment to compromised conditions of possibility whose realization is discovered either to be impossible, sheer fantasy, or too possible, and toxic"(Berlant 20I0, 94, original emphasis).

Let us say at the outset, then, that we use cruel optimism as a lens to explore the all-too-frequently neglected affective indeterminacies of our current moment, and not as an explanatory analytical device. In other words, we suggest that the hope for getting back to "normal" among the majority of Canadian publics is an affective paradox, which draws on technoscience as both its source and expression, even if that relationship might be fantasy or toxic. What makes this optimism about getting "back to normal" cruel, Berlant (2010; 20II) argues, is that the loss of this desire could be self-dissolution (or in this case societal dissolution). Even if the idea of normal in the context of a pandemic threatens well-being, the affective attachment to that double bind "provides something of the continuity of the subject's sense of what it means to keep on living on and to look forward to being in the world" (Berlant 20I0, 94). The loss of such a hope is the loss of the ability to be hopeful about anything. It is a desire that smooths 
over the complexities and indeterminacies within the working of biomedical science. In the first wave of public health briefings, we observe a zone of interaction between health officials and journalists that demonstrates a desire on the part of the media to smooth over complexity in order to seek news of hope and progress, leaving health officials to negotiate between the two. On one side is technoscientific hope and the desire to return to "normal." On the other is the need to find a resilient response that minimizes the health damage embodied by the population without further replicating harmful structures (YatesDoerr 2020). To put it glibly, perhaps too glibly, this is made more difficult by the fact that when people desire a return to "normal," they are wanting a return to the old white supremacist capitalist hetero-patriarchy that extensively damaged population health prior to the pandemic through its impact on the social determinants of health (Smallman 2020; Solar and Irwin 2010). In this regard consider, for example, how pandemic fatigue is putting talk of guaranteed incomes under erasure in favour of vaccine delivery as part of the logic of cruel optimism's double bind. Do we need to consider both in order to advance population health? Yes. But are both being equally discussed?

\section{Methodology}

We combine Holmes' and Krautwurst's prior ethnography in scientific settings with an analysis of Canadian public health briefings in order to provide context for the hopes and complexities surrounding technoscience within the pandemic. Holmes' research involved conference ethnography of proteomics science (or the large-scale study of proteins), as well as qualitative interviews with scientists (Holmes et al. 2016a; 20I6b; Holmes, McDonald and Jones 202I). Krautwurst's ethnographic research focused largely on participant observation within the offices or laboratories of neuroscientists. However, an effort to attend some of their professional meetings, described here, is helpful in learning about new research while observing networking in action.

We collected the public health briefings provided to the public from Ontario and Nova Scotia during the first wave of the pandemic from March 2020 to April 2020. While this does not represent "classic" fieldwork, as Seaver (2017) argues when discussing the anthropology of proprietary algorithms, the more experimental methodologies of recent years can salvage a great deal of important data to explain cultural phenomena. We use an ethnographic lens (Graham et al. 202I) to direct our attention towards how journalists and health officials interact within this data source. We combine this with perspectives from 
previous fieldwork, to analyze how public health deals with the complexities of technoscience when communicating with the public. We thematically coded these public health briefings for discussions of technoscience, including vaccines, COVID-I9 testing, and contact tracing. Ontario was chosen due to its controversy over testing in the province. These briefings were conducted by health officials alone. Nova Scotia was chosen because it laid out various specifics of testing and provides regular updates on the laboratory carrying out the testing. These briefings included both the premier and the chief medical officer. All briefings were publicly available on YouTube.

\section{Difficulties Developing Diagnostic Tests: A Tale of Proteomics}

In 2015, Holmes attended Clinic Day at the international Human Proteome Organization conference in Vancouver, BC. The day was full of scientific presentations about protein and gene testing, where presenters and participants discussed the myriad difficulties of getting diagnostic tests to meet clinical standards. The details varied, but the difficulties were constant: The journey of a year spent on optimizing a test to lower the error rate from to to 5 percent was described in such detail by a presenter, that a participant afterwards commented that the technical difficulties were daunting "enough to make you run back to the lab and just do basic research." Another presenter talked about choosing which assay to use that is good quality, but that does not require too much technical skill. A third suggested ways of getting around an immunoassay that showed a within-lab variability of 7 to 30 percent and a between-lab variability of 17 to 38 percent. In other words, results can be different up to 38 percent of the time, with the same sample, depending on who carries out the scientific protocol. This is far too high to put into clinical use. A different presenter

bemoaned the annoying problem of having their sample's peptides stick to the plastic tube they were using, meaning they lost 50 percent of their sample at every step in the protocol. The take-away message? Developing good diagnostic tests to work reliably in the clinic is difficult and people can and do devote years of their scientific life to this goal.

The last event of the day was a townhall panel discussing the regulation of diagnostic tests. With many US panelists and a Canadian panelist, they discussed the scientific, economic, and regulatory challenges of making sure that any new diagnostic test would meet adequate quality standards. Stories of US physicians who charge patients for omics diagnostic tests which the physician had no training to interpret correctly were passed around. Mentions were made 
of clinical diagnostic tests that need to be scientifically adjusted to allow for the altitude of the lab conducting the test in order to be accurate. The tests themselves, they argue, can only be standardized so far, which is why the laboratory has traditionally been the body that is certified.

The picture that emerges is that diagnostics are used regularly but can require constant tweaking in order to maintain a reasonable quality in the clinic. This requirement for adjustments complicates a straightforward standardization of diagnostic tests, as contexts are not completely interchangeable. In a good faith system, each lab needs to work out a reliable use of diagnostic tests that meets the quality standards that can be achieved elsewhere. Underlying this discussion was the taken-for-granted awareness that there will be no perfect scientific and regulatory solutions. Diagnostics are never perfect. The clinicians and scientists in the room were merely trying to get as close as possible to affordable, functional tests to determine illness within the bounds of the political economy of healthcare as they perceive it.

\section{Financing Basic Research: A Tale of Neuroscience}

It is 2015 and Krautwurst was at the international NeuroConX conference in Charlottetown, PEI. The theme that year was "Proteinopathies of Neurodegenerative Disorders." Following the closing comments by the organizers on the last day of the conference, many attendees flock to the sunshine of the outdoor patio overlooking the harbour for the wine and cheese reception. There he sees the Chief Financial Officer (CFO) of a local bioscience company meet up with someone whom he took to be his counterpart from an out-of-province small/medium enterprise (SME). "So," he says settling into his chair, "what's your burn rate?" Given his counterpart's puzzled expression, the CFO clarifies: "How fast do you go through your funds? How many million a year?" With that brief exchange Krautwurst learns a new phrase and better understands the precarity of SMEs relative to "Big Pharma." It also helped him understand why the conference was structured the way it was.

As the conference and theme titles suggested, the focus was on brain diseases such as Alzheimer's, Parkinson's, ALS, and schizophrenia. The research presented can be described as basic research with much attention given to the not-yet-well-understood mechanisms of neuronal inter- and intracellular breakdown. There was lively debate, for example, over whether certain brain disorders are variations on the "same" disorder, or whether they are in a different class or category altogether. Are Parkinson's and Alzheimer's variations on one 
another, or fundamentally distinct? Are brain plaques a cause or consequence of dementias? Of course, these debates also impinge on the kinds of treatments or diagnostic tests to be developed.

Unlike purely academic conferences, like the large annual Society for Neuroscience meetings, NeuroConX was intentionally small in scale and primarily a mix of academic and industry neuroscientists who work in SMEs. The research may have been basic, but as an industry-supported conference the goal was not only a better understanding of brain function at a more or less cellular level - though it was very much that - but also a search for marketable products to prevent, limit, or reverse neuronal malfunction. These possible products-in-the-making were mostly at preclinical stages (based on animal models and testing) or phase I (limited human testing) in the clinical trial classification system. Toward that end, the conference was structured so that academic and industry presentations alternated with each other, interspersed with partnering periods where people met in private rooms to discuss possible business arrangements for commercializing potential products or processes. The overwhelming majority of candidate products never reach pharmacy shelves for any of numerous reasons, ranging from price of production, to simply not working as anticipated, to effective but with severely toxic side-effects. One consequence of this is that bioscience SMEs are always seeking more funds and investors to move along potential products already being tested for safety and efficacy, while also researching new candidate products to replace the many that do not work. It begs questions of what is possible with more resources and fewer "strings attached" in basic research (and partly answered in the context of the pandemic).

\section{Science and COVID-19}

What does this have to do with COVID-I9? The messiness and challenge of much of this scientific labour is simply erased when the use of vaccines or COVID-I9 testing is discussed in the public briefings. We simply do not know the choices that are being made about diagnostic testing equipment, labour training, reagent use, and the difficulties of biological variation with which clinical science must contend. Dipping into the rapidly evolving scientific literature shows, for instance, that "the scientific basis for durable immunity, upon which [...] key public health and clinical strategies are dependent, is not well developed" (Huang et al. 2020, 4). There is some evidence to show that COVID-I9 will create an antibody response, but the numbers involved in such 
studies are limited and suggest that protection after infection will vary over time (perhaps only lasting one to two years), by individual (one person may have immunity longer than another), and by severity of symptoms (for example, asymptomatic individuals may not develop immunity) (Huang et al. 2020). Antibody testing is made more difficult by the fact that another variety of coronavirus may create false positives to such tests (Huang et al. 2020).

Diagnostic tests are complicated in that an ideal test is: I) rapid, 2) sensitive to the virus (that is, could detect small numbers of the virus), 3) specific to the virus you want to detect rather than other similar viruses (that is, cross-reactivity), and 4) uses equipment and laboratory skills appropriate to the clinical environment (Chafekar and Fielding 2018; Pang et al. 2020). Increased accuracy often correlates with more expensive equipment or slower tests, which is not optimal for clinical use (Chafekar and Fielding 20I8). Vaccine efficacy rests on the ability to create some kind of immune response. In addition, vaccine development hosts its own scientific challenges, such as finding the right target for a vaccine (Bhagavathula et al. 2020; Noorimotlagh et al. 2020), as well as myriad social challenges (Abbas 2020; Graham 2016; 2019; Harmon et al. 2020; Herder 2020; Sercovich 2020).

Technoscience, as both source and expression of cruel optimism amidst the pandemic, "works" insofar as the rest of the sociocultural and the biological context is assumed as relatively stable and determinate. In such a case, there is no perceived need to try novel social arrangements. But the scientific and social complexity argue for a more nuanced plan. How do health officials in public briefings negotiate these messy scientific details?

\section{Public Health and Technoscience}

Public health figures and public health briefings have experienced an enormous cultural rise in Canada since the beginning of the pandemic. Dr. Bonnie Henry in BC has a designer shoe and a ballad (Devlin 2020; Judd and Zussman 2020), Nova Scotia's public health briefings have been represented with Muppet memes and "Stay the Blazes Home" memorabilia (McKenna 2020; Patil 2020), Manitoba's health officials were memorialized in a Lego video that was set to Trudeau's speech to kids (CBC News 2020), and social media on PEI was enthralled with the wardrobe choices of Dr. Heather Morrison during formal media appearances. Their briefings during the pandemic have had considerable public reach and are widely accessible on YouTube. Chief Medical Officers represent the public face of public health. What do they tell the public about 
technoscience and COVID-I9? And what were journalists interested in asking about? This creates a zone of interaction between these two groups where impressions, information, and contradictions surrounding expert knowledge, science and technology, and optimism about the pandemic were co-created for the public. Riffing on how Anzaldúa (2009) describes the mestiza as a liminal figure who is a negotiator, translator, and mediator in Borderlands between cultural and linguistic worlds, we propose health officials in press briefings are liminal figures between clinical and scientific worlds, and those of the media. However, mediating and translating do not ensure understanding between individuals and groups. It is within this space of co-creation that we see the cultural pull of cruel optimism.

The briefings tend to focus on the facts and figures of the pandemic. Interactions combined scientific realism and hope. It is in the unsaid, however, where we see indications of cruel optimism manifested. Health officials do not mention the idea of a "new normal" or engage in speculations of the future, except when journalists' questions bring this up. Dialogue focused on the need for people to stay home, wash their hands, socially distance, and follow public health recommendations. While each province did this in their own style, the message was broadly the same: control the virus to return to some version of the status quo ante rather than engage in further program and policy experimentation toward forms of equity.

The majority of the time spent in these briefings in Nova Scotia and Ontario focused on case updates (new cases, current cases, the state of those cases, and deaths) and recommendations for public behaviour and current public health measures (for example, wash hands, social distance, stay home, what was closed and schedules for re-opening, and so on). The basics of this were explained multiple times. For example. Dr. Yaffe, in Ontario, had to explain over and over again that there was always a delay in the reporting of confirmed cases, due to the time needed to process tests for COVID-I9.

Most of the questions asked by journalists revolved around when the pandemic would peak, and when restrictions would be lifted. There was less concern for the pandemic itself and more concern around when life would get back to normal for individuals and businesses: public transport, bars, getting a cup of coffee with a friend, and other daily activities. Journalists scrutinized outbreaks that occurred in long term care homes and asked why that was happening. Public health briefings in Nova Scotia, where deaths were lower, marked each death with a ritualized, sentimental language of regret: "We are sorry 
to report... our thoughts go out to their family." In Ontario, while similar announcements began like that, as the pandemic progressed, numbers of deaths were high enough that they became mortality statistics that were largely factually stated. An exception was always made for the deaths of health care workers, which continued to be announced in more sentimental language.

Technoscientific complexity tended to creep into the briefings in response to journalists' questions about the future and technological advances, such as the advent of rapid or at-home diagnostic tests, or progress on vaccines. Journalists would repeatedly ask when "we would get back to normal." Such questions would often require health officials to engage in longer dialogues over the workings of science and technology. Officials would weave together responses that provided scientific realism and hope. After contesting scientific inaccuracies and unfounded hopes of the future that were based in technoscience, they always concluded that they remained hopeful and were monitoring innovations closely.

For example, when health officials are asked about diagnostic tests or vaccines, their explanations require unpacking of scientific difficulties. Their response, therefore, includes tamping down inflated expectations related to technoscientific possibilities. An example of this was a question asked of Dr. Yaffe in Ontario by a reporter about hope for the future; in which the uncertainty within scientific accuracy and realism are moderated by the desire for hope. The quote is implicitly about epidemiologically stabilizing the "population" in Foucault's (1998) biopolitical sense, and not stabilizing "society," although it is doubtful that journalists interpreted it this way. Here we see an example where "the science" is converted into affective energy via a "glimmer of hope.":

Reporter: Dr. Yaffe, the Premier talked about seeing a glimmer of light. [...] can you be specific about where that hope seems to come from?

Dr. Yaffe: Well, I mean, I am very hopeful as well but also, you know, with an abundance of caution and not assuming anything - because we have to keep working at the physical distancing and all the measures that we have in place.... generally, speaking, the number of new cases each day has been going down slightly [...] The modellers have told us that the peak is likely going to happen this week and that's assuming all the [public health] measures in place continue. So [...] if they are in fact 
correct and things continue after a peak, usually things go down. In Epidemiology the epidemic curve usually is symmetrical which means there will still be cases, but we'll be on the downside and so that does give me a glimmer of hope but with some caution built in. (Ontario Public Health Briefing, I3 April 2020: 6:52)

Within public health interactions with the media, "society" is envisioned or assumed as roughly the status quo. There is no sense that science can be the basis for a different kind of society. We discuss further instances of "hope with caution built in" as they relate to scientific complexity for testing and vaccines below.

\section{On Testing Reliability and Scientific Complexity}

Diagnostic testing, particularly for a new test, is not a straightforward process. Dr. Strang demonstrates this in his response to a journalist's question about what a "presumed case" means:

Dr. Strang: We do not have the capacity at our lab ... It's not been validated yet. It's coming soon, that [it will be] reliable enough to report a positive result from our lab. It still has to go to the national lab.

At this point in time, we will only be reporting a case when it's confirmed from the national lab. Once we get the final validation of our lab, we would then be able to report a presumptive case because we will be confident on our results in our lab. But it would still have to be confirmed at the national lab in Winnipeg and we're not quite there yet. (Nova Scotia, Public Health Briefing, I3 March 2020, 21:50)

In this and other briefings (for example, 7 April 2020), he makes clear that skilled human labour and equipment is necessary for a robust testing system. However, the scientific reliability of testing, even when your human capacity is up and running, still has to contend with the messy reality of how the virus manifests itself in the human body.

Dr. Strang: There are medical reasons why somebody may test negative. If they're very early on in the disease they may have what we call a very low viral load, so not a lot of virus in your upper airway - the nose and throat - where we take the swab from. The other reason is that if people have a disease deep in their lungs, they may well not actually have the virus in their nose and throat [...] there's potential for a negative test and that is the reason [...] that anybody with a suspicion of respiratory 
disease related to COVID gets put on and is maintained on appropriate precautions even if their initial test came back negative. (Nova Scotia Public Health Briefing, 8 April 2020, 32:II)

These complexities and indeterminacies extend also to the ability to test for antibodies that might show an individual has immunity to COVID-I9. This involves proving: (I) that an individual actually had COVID-I9; (2) that infection generates later immunity, and (3) that you can accurately test for that immunity, as Dr. Williams demonstrates in a response to a journalist's question about immunity to COVID-I9 and "immunity passports" for international travel:

Dr. Williams: So, that's part of the evolving science [...] when you hear about these re-infections. Of course, one has to be sure that the person was initially infected. That may seem odd to say, but if you take a person who is swabbed [...] they may not have enough infection to give an overall, the term is viremia, and you need that to stimulate the whole immune system [...] Then you need to measure that through the so-called serological testing [from blood tests]. There are some serological tests out there now, unfortunately they're not as sensitive as we'd like them to be. [...] some of these tests out there could give you some false pretense and then you get infected and you wonder what went wrong. So again, if you're going to test you gotta make sure you can rely upon it and that you're sure that the person does have immunity and then to give him some sense of confidence [...] We hope that the serological testing might be available over the summer.

[...] I don't want to get into too much technology here, but there's immune globulins of different types [...] We want to make sure the testing is good, the testing is available, and the interpretation of the testing is evidence based and proven. (Ontario Public Health Briefing, 25 April 2020: 12:36)

For the most part, such indeterminacies lie below the surface, unexplained to and unsought by journalists. The lack of such explanation, creating testing as a solid "black box" in the interaction between journalists and health officials, perpetuates the larger social-cultural context. Indeterminacies of scientific testing and indeterminacies of socio-cultural structures that may cause harm are both smoothed over. In the absence of explicitly stated alternatives most people default to some version of the status quo ante. 


\section{On Vaccines, Scientific Complexity, and Hope}

Vaccines are one of the key concerns raised repeatedly in relation to a return to normal, with the virus no longer considered a threat. Questions bring up the response that "we're not there yet" and focus on the long-time window required for vaccine development, and, as such, reinforce not only the biomedical indeterminacies, but the socio-cultural ones as well.

Reporter: On the vaccine front there are reports circulating that we are looking at a two year wait period [...] Would you mind commenting on that?

Yaffe: Well, I can comment in general. [...] there's lots of different people across the world trying to develop vaccines for this, which of course will be really valuable once we get them. Once they've been tested to be safe and effective. Usually, a vaccine takes at least I8 months. Anything less than that is being extremely optimistic [...] but we're keeping up to date obviously with what's happening and remain hopeful. (Ontario Public Health Briefing, 4 April 2020: 18:48)

In Nova Scotia, vaccines were not mentioned in the period under study but they did come up under questions about how we "return to normal" during the 22 July 2020 return-to-school briefing. We include the quote to show the beginnings of a public health questioning of how useful vaccines may be in the future in an evolving conversation between public health and the media.

Reporter: At the end of the day, is it the vaccine that is going to make it go back to a more normal situation?

Dr. Strang: That's a big question. There is a lot that we don't know about this virus and there's a lot that we don't know about the vaccine. And you know a lot of people look to the vaccine as a solution, but if you talk to a number of action experts, you know, we look at influenza vaccine. That is modestly effective. [...] I think you've got to be cautious and not put all our eggs ... that a vaccine is going to solve everything. (Nova Scotia Public Health Briefing, 22 July 2020: 34:02)

These perspectives contrast with media reports on vaccines, such as a Guardian article that came out at the same time suggesting that "scientists are hoping to develop a coronavirus vaccine within I2 to I8 months" (Kommenda and HulleyJones 2020). Their own update on clinical trials, however, showed only five vaccines in efficacy trials that provide data on whether or not a vaccine works. 
Ignoring the indeterminacies of vaccines and scientific complexity mentioned above continued into more recent announcements of viable vaccine candidates, which are requesting emergency regulatory approval (The Associated Press 2020). Questions reported in the Canadian media focus on when Canadians will have access to vaccines (Jones 2020) and not on how we will track how well they work and for which populations (Herder 2020). This difference is immaterial if the vaccines are perfect, but if they are not, obscuring the scientific indeterminacies may result in vaccine backlash after the optimism about the vaccines as a cure-all proves cruel.

Health officials in these situations often do not directly confront hope for easier, more accurate testing, treatments, and vaccines. Their role in such interactions is to try to bring the discussion back to the basics of their media message for the public. However, this lack of challenge, we suggest, in combination with a lack of journalistic engagement with scientific indeterminacies, decreases the possibility for conversations that might permit more realistic expectations for the public and the possibility of improving conditions that worsen the pandemic. While this approach is successful in avoiding mass panic, would a more brutal honesty about scientific complexities and the need for change build better resilience in the long run? The 22 July 2020 quote from Dr. Strang may suggest a move in this direction. Change is hard, but so is the reality that what we started "for a little while" in the pandemic's first wave can go on for some time in ways to which we need to adjust and/or we will need to experiment with ways that challenge the structures that worsened this mess.

\section{Conclusion}

Benton (2020) argues for the importance of imagining health starting in communities and that public health needs to value something other than cost in order to grow in a way that will allow communities to thrive through COVID-I9. We suggest that part of that re-imagining is a discourse that allows a more realistic perspective on technoscience's strength and weaknesses. Technology is a sociopolitical tool (Winner 1980), and we need to be thinking about people and communities through the social relations embedded in technology. We also need to include its complexities in a way that allows our optimism to be less cruel.

The interaction between health officials and journalists left the affective paradoxes of which Berlant speaks largely intact. Technoscientific and 
socio-political complexities largely remained as footnotes. Unless one is paying careful attention, the media messages largely left one in a space where, as Berlant phrases it, you are "at home in yourself bathed by emotions you can always recognize and that whatever material harshness you live is not the real, but an accident that you have to clean up after, which will be more pleasant if you whistle while you work." (Berlant 20IO, I04). With ever increasing signs of pandemic fatigue, the perceived resolution of the double bind of cruel optimism drifts toward the fantasy that the past was not so bad after all, "even with the image of a better good life available" (Berlant 20II, 263)

\section{Christina Holmes,}

St.Francis Xavier University, cholmes@stfx.ca

\section{Udo Krautwurst,}

University of Prince Edward Island, ukrautwurst@upei.ca

\section{Kate Graham,}

St. Francis Xavier University, x2oI8xyd@stfx.ca

\section{Victoria Fernandez,}

St.Francis Xavier University, x20I8twi@stfx.ca

\section{Acknowledgements}

We would like to thank Kamy Roberge-Carrington, Brianna Gottschall, and Dr. Adia Benton for conversations about other projects and the evolving pandemic that were extremely useful for idea cross-fertilization for this paper. Also, Keeha and Corbin Wyeth for putting up with academic parents during the pandemic. Portions of this research were funded through the Canadian

Institutes of Health Research, OGH-III4O2, "Articulating Standards: Translating the Practices of Standardizing Health Technologies," an Australian Government Endeavour Research Fellowship, and a St. Francis Xavier University Council for Research Grant.

\section{References}

Abbas, Muhammad Zaheer. 2020. "Practical Implications of 'Vaccine Nationalism': A Short-Sighted and Risky Approach in Response to Covid-I9." Research Paper. South Centre. Geneva: South Centre, November. https://www.southcentre.int/wpcontent/uploads/2020/II/RP-I24.pdf. 
Anzaldúa, Gloria E. 2009. "The New Mestiza Nation.” In The Gloria Anzaldúa Reader, edited by AnaLouise Keating, 203-216. Durham, NC: Duke University Press.

Beisel, Uli, and Christophe Boëte. 2013. "The Flying Public Health Tool: Genetically Modified Mosquitoes and Malaria Control." Science as Culture 22 (I): 38-6o. https:// doi.org/IO.IO80/0950543I.2013.776364.

Benton, Aida, interview by John Githongo. 2020. Dr Adia Benton: COVID-I9 Interventions Will Become Part of Our Social Fabric https://africauncensored.online/covid-I9conversations-I2/.

Berlant, Lauren. 20I0. "Cruel Optimism." In The Affect Theory Reader, edited by Melissa Gregg, Gregory J. Seigworth and Sara Ahmed, 93-I37. Durham, NC: Duke University Press.

——. 20II. Cruel Optimism. Durham, NC: Duke University Press.

Bhagavathula, Akshaya S., Wafa A. Aldhaleei, Alessandro Rovetta, and Jamal Rahmani. 2020. "Vaccines and Drug Therapeutics to Lock Down Novel Coronavirus Disease 2019 (COVID-I9): A Systematic Review of Clinical Trials.” Cureus I2 (5): e8342. https://doi.org/IO.7759/cureus.8342.

CBC News. 2020. “The Message Might Get across Better’: Winnipeg Family Builds Lego Video of PM's COVID-I9 Message to Kids." CBC News. 7 April. Accessed I August 2020. https://www.cbc.ca/news/canada/manitoba/lego-video-coronavirusI. 5524282 .

Chafekar, Aasiyah, and Burtram C. Fielding. 20I8. "MERS-CoV: Understanding the Latest Human Coronavirus Threat.” Viruses Io (2): 93. https://doi.org/I0.3390/ vioo20093.

Davis-Floyd, Robbie E. 1994. "The Technocratic Body: American Childbirth as Cultural Expression." Social Science E Medicine 38 (8): II25-II40. https://doi.org/IO.IOI6/o2779536(94)90228-3.

DelVecchio Good, Mary-Jo. 200I. “The Biotechnical Embrace.” Culture, Medicine and Psychiatry 25 (4): 395-4IO. https://doi.org/IO.IO23/A:IOI3097002487.

DelVecchio Good, Mary-Jo, Byron J. Good, Cynthia Schaffer, and Stuart E. Lind. I990. "American Oncology and the Discourse on Hope." Culture, Medicine and Psychiatry I4 (I): 59-79. https://doi.org/IO.IOO7/BFooo46704.

Devlin, Mike. 2020. "Island Musician Scores a Hit with Ballad of Bonnie Henry." Times Colonist. 8 April. Accessed I August 2020. https://www.timescolonist.com/enter tainment/island-musician-scores-a-hit-with-ballad-of-bonnie-henry-I.24II42II. 
Fortun, Michael. 2008. Promising Genomics: Iceland and DeCODE Genetics in a World of Speculation. Berkeley, CA: University of California Press.

Foucault, Michel. I998. The Will to Knowledge: The History of Sexuality, Volume I: An Introduction. 1976. Translated by Robert Hurley. London: Penguin.

Franklin, Sarah, and Celia Roberts. 2006. Born and Made: An Ethnography of Preimplantation Genetic Diagnosis. Princeton: Princeton University Press.

Graham, Janice. 20I6. "Ambiguous Capture: Collaborative Capitalism and the Meningitis Vaccine Project." Medical Anthropology 35 (5): 419-432. https:/doi.org/ I0.I080/0I459740.20I6.II67055.

—_. 2019. "Ebola Vaccine Innovation: A Case Study of Pseudoscapes in Global Health." Critical Public Health 29 (4): 4OI-4I2. https://doi.org/IO.IO80/0958I596.20I9.I597966.

Graham, Janice E., Christina Holmes, Fiona McDonald, and Regna Darnell. 202I. "Introduction." In Engagement, The Social Life of Standards: Ethnographic Methods for Local Engagement, edited by Janice Graham, Christina Holmes, Fiona McDonald and Regna Darnell, 3-2I. Vancouver: UBC Press.

Harmon, Shawn H. E., David Faour, Noni E. MacDonald, Janice Graham, Christoph Steffen, Louise Henaff, and Stephanie Shendale. 2020. "Strengthening Vaccination Frameworks: Findings of a Study on the Legal Foundations of National Immunization Technical Advisory Groups (NITAGs)." Vaccine 38 (4): 840-846. https://doi.org/IO.IOI6/j.vaccine.20I9.IO.085.

Herder, Matthew. 2020. "Transparency Too Little, Too Late? Why and How Health Canada Should Make Clinical Data and Regulatory Decision-making Open to Scrutiny in the Face of COVID-I9." OSF Preprints. 5 November. https://doi. org/Io.3I2I9/osf.io/evhnk.

Holmes, Christina, Fiona McDonald, and Mavis Jones. 202I. "When Are Standards Necessary in the Lab? Standards as Gateway or Barrier to Innovation in Proteomics." In The Social Life of Standards: Ethnographic Methods for Local Engagement, edited by Janice Graham, Christina Holmes, Fiona McDonald and Regna Darnell, 63-67. Vancouver: UBC Press.

Holmes, Christina, Siobhan M. Carlson, Fiona McDonald, Mavis Jones, and Janice Graham. 20I6a. "Exploring the Post-Genomic World: Differing Explanatory and Manipulatory Functions of Post-Genomic Sciences." New Genetics and Society 35 (I): 49-68. https://doi.org/IO.IO80/I4636778.20I5.II33280. 
Holmes, Christina, Fiona McDonald, Mavis Jones, and Janice Graham. 20I6b. "Knowledge Translation: Moving Proteomics Science to Innovation in Society." OMICS: A Journal of Integrative Biology 20 (6): 352-36I. https://doi.org/IO.IO89/ omi.2016.0032.

Huang, Angkana T., Bernardo Garcia-Carreras, Matt Hitchings, Bingyi Yang, Leah Katzelnick, Susan M. Rattigan, Brooke A. Borgert, Carlos A. Moreno, Benjamin D. Solomon, Luke Trimmer-Smith, Veronique Etienne, Isabel Rodriguez-Barraquer, Justin Lessler, Henrik Salje, Donald S. Burke, Amy Wesolowski, and Derek A. T. Cummings. 2020. "A Systematic Review of Antibody Mediated Immunity to Coronaviruses: Antibody Kinetics, Correlates of Protection, and Association of Antibody Responses with Severity of Disease." Nature Communications II (4704): I-I6. https://doi.org/IO.IO38/s4I467-020-I8450-4.

Jones, Ryan Patrick. 2020. "Canada 'Not at the Back of the Line' for COVID-I9 Vaccine, Moderna Chairman Says.” CBC News. 29 November. Accessed 29 November 2020. https://www.cbc.ca/news/politics/canada-vaccine-moderna-covid-I9-hadjuhealth-I.582II66.

Judd, Amy, and Richard Zussman. 2020. "Dr. Henry Shoes Sell out as Fluevog Website Crashes amidst Excitement.” Global News. 23 April. Accessed I August 2020. https:// globalnews.ca/news/6860502/bonnie-henry-shoe-john-fluevog-presale-startthursday/.

Kommenda, Niko, and Frank Hulley-Jones. 2020. "Covid Vaccine Tracker: When Will We Have a Coronavirus Vaccine?” The Guardian. 8 August. Accessed I August 2020. https://www.theguardian.com/world/ng-interactive/2020/aug/o8/covidvaccine-tracker-when-will-we-have-a-coronavirus-vaccine.

Latour, Bruno. 1987. Science in Action: How to Follow Scientists and Engineers through Society. Cambridge, MA: Harvard University Press.

McKenna, Cora. 2020. "Name That Iconic Duo: Stephen McNeil and Robert Strang." The Coast Halifax. 27 March. Accessed I August 2020. https://www.thecoast.ca/ COVIDi9Needtoknow/archives/2020/03/27/name-that-iconic-duo-stephenmcneil-and-robert-strang.

Montenegro de Wit, Maywa. 20I6. "Are We Losing Diversity? Navigating Ecological, Political, and Epistemic Dimensions of Agrobiodiversity Conservation." Agriculture and Human Values 33 (3): 625-640. https://doi.org/I0.I007/sI0460oI5-9642-7. 
Noorimotlagh, Zahra, Chiman Karami, Seyyed Abbas Mirzaee, Mohammadreza Kaffashian, Sanaz Mami, and Mahdieh Azizi. 2020. "Immune and Bioinformatics Identification of T Cell and B Cell Epitopes in the Protein Structure of SARSCoV-2: A Systematic Review." International Immunopharmacology 86: I06738. https:// doi.org/Io.IoI6/j.intimp.2020.I06738.

Novas, Carlos. 2006. "The Political Economy of Hope: Patients' Organizations, Science and Biovalue." BioSocieties I (3): 289-305. https://doi.org/IO.IOI7/SI745855206003024.

Pang, Junxiong, Min Xian Wang, Ian Yi Han Ang, Sharon Hui Xuan Tan, Ruth Frances Lewis, Jacinta I-Pei Chen, and Ramona A. Gutierrez. 2020. "Potential Rapid Diagnostics, Vaccine and Therapeutics for 2019 Novel Coronavirus (2019-NCoV): A Systematic Review." Journal of Clinical Medicine 9: 623. https:/doi.org/I0.3390/ jcm9030623.

Patil, Anjuli. 2020. "Premier's 'Stay the Blazes Home' Inspires Music, Merchandise, Memes.” CBC Nova Scotia. 4 April. Accessed I August 2020. https://www.cbc.ca/ news/canada/nova-scotia/stay-the-blazes-home-inspires-music-merchandisememes-I.5522068.

Reynolds, Peter. 1991. Stealing Fire: The Mythology of the Technocracy. Palo Alto, CA: Iconic Anthropology Press.

Seaver, Nick. 2017. "Algorithms as Culture: Some Tactics for the Ethnography of Algorithmic Systems." Big Data E Society 4 (2). https://doi.org/I0.II77/205395 I717738104.

Sercovich, Francisco Colman. 2020. "Coronavirus Pandemic: The Vaccine as Exit Strategy; A Global Hurdle Race against Time with a Split Jury.” SouthViews 203 (July 24). https://www.southcentre.int/southviews-no-203-24-july-2020/.

Smallman, Melanie. 2020. "'Nothing To Do with the Science': How an Elite Sociotechnical Imaginary Cements Policy Resistance to Public Perspectives on Science and Technology through the Machinery of Government." Social Studies of Science 50 (4): 589-608. https://doi.org/I0.II77/03063.

Solar, O., and A. Irwin. 2010. "A Conceptual Framework for Action on the Social Determinants of Health." Social Determinants of Health Discussion Paper 2 (Policy and Practice). Geneva: World Health Organization. https://www.who.int/sdhconference/resources/ConceptualframeworkforactiononSD_eng.pdf.

Stone, Glenn Davis, and Dominic Glover. 2017. "Disembedding Grain: Golden Rice, the Green Revolution, and Heirloom Seeds in the Philippines." Agriculture and Human Values 34 (I): 87-IO2. https://doi.org/IO.IO07/sIO460-0I6-9696-I. 
The Associated Press. 2020. "Moderna to Ask U.S., European Regulators to OK Emergency Use of COVID-I9 Vaccine.” CBC News. 30 November. Accessed I December 2020. https://www.cbc.ca/news/health/moderna-regulators-vaccineI.5821638.

Winner, Langdon. 1980. “Do Artifacts Have Politics?” Daedalus I09 (I): I2I-I36.

Yates-Doerr, Emily. 2020. "Reworking the Social Determinants of Health: Responding to Material-Semiotic Indeterminacy in Public Health Interventions." Medical Anthropology Quarterly. https://doi.org/IO.IIII/maq.I2586. 